\title{
Comparative Studies on the Bioremediation of Used Engine Oil Contaminated Soil using Urea Fertilizer (UF), Goat Manure (GM), Pig Manure (PM) and Brewery Spent Grain (BSG)
}

\author{
Ilaboya I. R. ${ }^{1 *}$ and Otuaro E. A. ${ }^{2}$ \\ ${ }^{1}$ Department of Civil Engineering, University of Benin, Benin City, Edo State, Nigeria \\ ${ }^{2}$ Department of Civil Engineering, Delta State University, Abraka, Delta State, Nigeria \\ Corresponding Author: *rudolph.ilaboya @uniben.edu
}

\begin{abstract}
The focus of the study was to evaluate and compare the performance of urea fertilizer, goat manure, pig manure and brewery spent grain for the bioremediation of used engine oil contaminated soil. Soil with no pollution history was collected and subjected to detailed laboratory analysis to determine the total heterotrophic bacterial population, $\mathrm{pH}$, moisture content, total organic carbon, total nitrogen and total hydrocarbon content. Used engine oil contaminated soil was prepared by adding $250 \mathrm{~g}$ of used engine oil into a clean dry plastic bucket containing $1 \mathrm{~kg}$ of unpolluted soil. The mixture was properly mixed and covered with aluminium foil paper before use. The used engine oil contaminated soil was left for a period of four (4) days for stabilization before the commencement of treatment. The entire setup and its content was open throughout the period of experimentation to allow for the influence of atmospheric oxidation. The setup was monitored for twelve (12) weeks and sampling/analysis of the samples was done on a weekly basis to ascertain the progress of treatment. The residual hydrocarbon content after each treatment was determined using Atomic Absorption Spectrophotometer. Results obtained shows that pig manure is the best substrate for the clean-up of used engine oil contaminated soil with calculated removal efficiency of $64.4 \%$ followed by BSG with 51.4\% removal efficiency, Goat Manure with removal efficiency of $39.9 \%$ and Urea Fertilizer with 33.7\% efficiency. The kinetic modelling shows that experimental data fitted well with pseudo-first order kinetic model with calculated error sum of square (SSE) values of $(0.0002,0.0005,0.0012$ and 0.0072) and root mean square errors (RMSE) of (0.0028, $0.0073,0.0082$ and 0.0481$)$. On the accurate prediction of the optimum remediation time, it was observed that the non-linear regression model gave higher coefficient of determination of 0.9824 , $0.9812,0.9886$ and 0.9899 compared to linear regression.
\end{abstract}

Keywords: Bioremediation, Total organic carbon (TOC), Pseudo-first order model, Nonlinear regression, Residual hydrocarbon content

\subsection{Introduction}

Bioremediation is the use of microorganism metabolism to remove pollutants from soil and water. Bioremediation can occur on its own (natural attenuation or intrinsic bioremediation) or can be spurred on via the addition of fertilizers to increase the bioavailability within the medium (biostimulation). Recent advancements have also proven successful via the addition of matched microbe strains to the medium to enhance the resident microbe population's ability to break down contaminants. Bioremediation can be classified as in-situ or ex-situ. When bioremediation is carried out at the site of contamination, then it is in-situ but when the contaminated soil is removed from the original site, then it became ex-situ bioremediation (Vidali, 2001). A number of technologies have been tested to remediate sites that are contaminated with hydrocarbon products such as incineration plants which have been developed to clean up hydrocarbon contaminated sites. Incineration method of hydrocarbon cleanup has the advantage of short treatment time, but the system requires huge machines and large amounts of heavy oils (Burland and Edward, 1999). Biological treatments for hydrocarbon-degradation have also been investigated and have be found to be less sophisticated 
natural method of cleanup of hydrocarbon polluted sites, but the low solubility and adsorption of high molecular weight hydrocarbons limits their availability to microorganisms (Grossi et al., 2002). The specificity of the degradation process is related to the genetic potential of the particular microorganism to introduce molecular oxygen into hydrocarbon and to generate the intermediates that subsequently enter the general energy- yielding metabolic pathway of the cell. Positive effects of nitrogen amendment using nitrogenous fertilizer on microbial activity and petroleum hydrocarbon degradation have been widely demonstrated. However, in developing countries, inorganic chemical fertilizers are costly as well as not sufficient for agriculture, let alone for cleaning oil spills; hence, the search for cheaper and environmentally friendly options of enhancing petroleum hydrocarbon degradation. One of such options is the use of organic wastes effluents that could act as bulking agents and also as bacterial biomass suppliers. There are few literatures on the potential use of these organic wastes effluents as biostimulating and bioaugmentation agents. However, some researchers have investigated the potential use of solid organic wastes such as sugarcane bagasse (MolinaBarahona et al., 2004), brewery spent grain (Abioye et al., 2009) and animal wastes like cow dung (Akinde and Obire, 2008), poultry manure (Okiemen and Okiemen, 2005), goat manure (Agarry et al., 2013), and sewage sludge (Mao and Yue, 2010) as biostimulating agents in the cleanup of soil contaminated with petroleum hydrocarbons and were found to show positive influence on petroleum hydrocarbon biodegradation in a polluted environment.

However, there is need to investigate the performance of these organic waste materials as agent for the bioremediation of used engine oil contaminated soil. Furthermore, comparative evaluation of these organic waste materials has not been reported in the literature. Therefore, the focus of this study is to carry out a comparative evaluation on the potential of urea fertilizer, goat manure, pig manure and brewery spent grain in the bioremediation of used engine oil contaminated soil.

\subsection{Materials and Methods}

Slight modification of the method presented in Agarry et al. (2010) was employed in the preparation of used engine oil contaminated soil as follows; $10 \mathrm{~kg}$ of unpolluted soil was weighed into a plastic bowl and $2.5 \mathrm{~kg}$ of concentrated used engine oil was added gradually and was properly mixed. The moisture content of the used engine oil contaminated soil was determined immediately after mixing. The contaminated soil sample was left for 4days for stabilization before the commencement of treatment process. Prior to treatment, the physico-chemical and microbial properties of the contaminated and uncontaminated soil sample was carried out after digestion (using 1:1 ratio of $0.25 \mathrm{M}$ hydrochloric acid and nitric acid) to determine the effects of used engine oil contamination on the intrinsic properties of the uncontaminated soil. To commence the treatment process, $10 \mathrm{~kg}$ used engine oil contaminated soil was shared into four (4) equal parts with each portion placed in clean plastic bucket perforated at the bottom. The clean plastic bucket and its content were placed outside and open throughout the period of experimentation to allow for the influence of atmospheric oxygen.

The details of the batch experiment are presented below:

i. To the first plastic bucket, 2000:500 (w/w) mixtures of the contaminated soil and inorganic fertilizer (urea) in addition to $20 \mathrm{ml}$ nutrient broth was thoroughly mixed and stored in cool dry place for further investigation.

ii. To the second plastic bucket, 2000:500 (w/w) mixtures of the contaminated soil and pig manure in addition to $20 \mathrm{ml}$ nutrient broth was thoroughly mixed and stored in cool dry place for further investigation.

iii. To the third plastic bucket, 2000:500 (w/w) mixtures of the contaminated soil and goat manure in addition to $20 \mathrm{ml}$ nutrient broth was thoroughly mixed and stored in cool dry place for further investigation.

iv. To the fourth plastic bucket, 2000:500 (w/w) mixtures of the contaminated soil and Brewery Spent Grain (BSG) in addition to $20 \mathrm{ml}$ nutrient broth was thoroughly mixed and stored in cool dry place for further investigation.

v. The fifth plastic bucket contains $2000 \mathrm{~g}$ of the contaminated soil with no treatment medium. This setup was taken as the control experiment used to monitor the progress of remediation.

The treatment process commenced after 4days and samples were collected weekly for a period of twelve weeks to be tested for chemical and microbial properties, namely; $\mathrm{pH}$, electrical conductivity, 
total hydrocarbon content (THC), total heterotrophic bacterial (THB), total organic carbon, total nitrogen content. The progress of remediation was assessed based on changes in the concentration of these variables with treatment time. The environmental temperature was maintained within the range of $30-32^{\circ} \mathrm{C}$ throughout the period of experimentation and the moisture content was kept in the range of $45-50 \%$ for maximum remediation. The amount of used engine oil degradation during the series of batch investigation was determined using the mass balance equation reported in Raghuvanshi et al. (2004) as follows:

$q=\frac{v}{m}\left(C_{0}-C_{e}\right)$

Where: $\mathrm{q}$, defines the used engine oil uptake $(\mathrm{mg} / \mathrm{g}) ; \mathrm{C}_{0}$ and $\mathrm{C}_{\mathrm{e}}$ : are the initial and equilibrium used engine oil concentrations in the digested soil solution $[\mathrm{mg} / \mathrm{l}]$ respectively; $\mathrm{V}$ : is the weight of contaminated soil sample taken $(\mathrm{g})$ and $\mathrm{M}$ : is the mass of substrate used $(\mathrm{g})$. The efficiency of used engine oil degradation (\%) during the series of batch experimentation was computed based on the mathematical equation reported in Eba et al. (2010) as follows:

Efficiency $(\%)=\frac{100}{C_{0}}\left(C_{0}-C_{e}\right)$

Where: $\mathrm{C}_{0}$ and $\mathrm{C}_{\mathrm{e}}$ are the used engine oil concentration measured in terms of the total hydrocarbon content $(\mathrm{mg} / \mathrm{l})$ in digested soil solution before and after treatment.

To study the kinetics of used engine oil degradation, data obtained from the series of batch experimentation were analyzed using selected reaction controlled and diffusion controlled kinetic models, namely; pseudo-first order kinetic model, pseudo-second order kinetic model, film diffusion model and intra-particle diffusion model. The underlying mathematical equations and the plot parameters of the selected kinetic models are presented in Table 1.

Table 1: Definition of selected kinetic models

\begin{tabular}{|l|lc|l|}
\hline Kinetic Model & \multicolumn{1}{|c|}{ Kinetic Equation } & \multicolumn{1}{|c|}{ Plot Parameters } \\
\hline Pseudo-First Order & $\ln \left(q_{e}-q_{t}\right)=\ln \left(q_{e}\right)-k t$ & (3) & $\begin{array}{l}\ln \left(q_{e}-q_{t}\right) \text { against (t) (Lagergren and } \\
\text { Svenska, 1998) }\end{array}$ \\
\hline Pseudo-Second Order & $q_{t}=\frac{k_{2} q_{e}^{2} t}{1+q_{e} k_{2} t}$ & $\left(\frac{t}{q_{t}}\right)$ against (t) (Shamik and Papita, 2010) \\
\hline Film Diffusion & $\ln \left(\frac{C_{t}}{C_{0}}\right)=-\left[\frac{K_{f} \cdot W \cdot S_{w}}{V_{f}}(t)\right]$ & (5) & $\left(\frac{C_{t}}{C_{0}}\right)$ against (t) (Van-Lier, 1989) \\
\hline Intra-Particle Diffusion & $q_{t}=K_{a d} t^{\frac{1}{2}}+I$ & (6) & $\left(q_{t}\right)$ against (t $\left.\mathrm{t}^{\frac{1}{2}}\right)$ (Ashtoukhy et al., 2008) \\
\hline
\end{tabular}

Where;

$q_{e}$ is amount of used engine oil removed at equilibrium (mg.g-1)

$q_{t}$ is amount of used engine oil removed at time ( $\left.\mathrm{t}\right)(\mathrm{mg} \cdot \mathrm{g}-1)$

$K_{l}$ is rate constant of pseudo first-order adsorption $\left(\mathrm{gmg}^{-1} \mathrm{~min}^{-1}\right)$

$K_{2}$ is rate constant of pseudo first-order adsorption $\left(\mathrm{gmg}^{-1} \mathrm{~min}^{-1}\right)$

$K_{f}$ is the mass transfer coefficient for film diffusion

$S_{\mathrm{w}}$ is the specific external surface of substrate on weight basis

$W$ is substrate dosage

$V_{f}$ is the volume of the fluid (used engine oil)

$K_{a d}$ is intra-particle diffusion rate constant ( $\left.\mathrm{mg} / \mathrm{g} \mathrm{min}\right)$ and

$I$ is the thickness of boundary layer 


\subsection{Results and Discussion}

The physico-chemical properties of the experimental soil which include; the moisture content, $\mathrm{pH}$, electrical conductivity, organic carbon, total nitrogen and total hydrocarbon content are presented in Table 2.

Table 2: Physico-chemical properties of uncontaminated soil

\begin{tabular}{|l|l|l|}
\hline S/N & Parameter & Test Result \\
\hline 1 & Moisture Content $(\%)$ & 2.6 \\
2 & $\mathrm{pH}$ & 9.4 \\
3 & Electrical Conductivity $(\mu \mathrm{s} / \mathrm{cm})$ & 30 \\
4 & Total Dissolved Solids $(\mathrm{mg} / \mathrm{l})$ & 19.8 \\
5 & Organic Carbon $(\mathrm{g} / \mathrm{kg})$ & 6.21 \\
6 & Total Nitrogen $(\mathrm{g} / \mathrm{kg})$ & 7.23 \\
7 & Total Hydrocarbon Content $(\mathrm{mg} / \mathrm{kg})$ & 0.00 \\
8 & Total Heterotrophic Bacterial $(\mathrm{cfu} / \mathrm{g})$ & $8 * 10^{5}$ \\
\hline
\end{tabular}

Results of Table 2 revealed that the experimental soil is highly alkaline with a $\mathrm{pH}$ of 9.4, bone dry with a moisture content of $2.6 \%$ with nutritive values measured in terms of total organic carbon and total nitrogen content of 6.21 and $7.23 \mathrm{~g} / \mathrm{kg}$ respectively. The soil also possesses very low concentration of dissolved solids and electrical conductivity $(30 \mu \mathrm{S} / \mathrm{cm}$ and $19.80 \mathrm{mg} / \mathrm{l}$ respectively). It was also observed from Table 2 that the soil was completely free from crude petroleum hydrocarbon pollution as evident from the result of total hydrocarbon content. The physico-chemical properties of the used engine oil used for this study are presented in Table 3.

Table 3: Physico-chemical properties of used engine oil

\begin{tabular}{|l|l|l|}
\hline S/N & Parameter & Test Result \\
\hline 1 & Specific Gravity & 2.467 \\
2 & pH & 4.1 \\
3 & Dynamic Viscosity $(\mathrm{g} / \mathrm{cm} . \mathrm{s})$ & 3.567 \\
4 & Electrical Conductivity $(\mu \mathrm{s} / \mathrm{cm})$ & 234 \\
\hline
\end{tabular}

Addition of used engine oil to the experimental soil resulted in the contamination of the soil which invariably altered the initial physico-chemical properties of the soil. Results of changes in the soil physico-chemical properties occasioned by the addition of used engine oil are presented in Table 4.

Table 4: Effect of used engine oil contamination on the soil physico-chemical properties

\begin{tabular}{|l|l|l|l|}
\hline $\mathrm{S} / \mathrm{N}$ & Parameters & Before contamination & After contamination \\
\hline 1 & Moisture Content $(\%)$ & 2.6 & 40 \\
2 & $\mathrm{pH}$ & 9.4 & 3.6 \\
3 & Electrical Conductivity $(\mu \mathrm{s} / \mathrm{cm})$ & 30 & 80 \\
4 & Total Dissolve Solids $(\mathrm{mg} / \mathrm{l})$ & 19.8 & 52.8 \\
5 & Organic Carbon $(\mathrm{g} / \mathrm{kg})$ & 6.21 & 3.15 \\
6 & Total Nitrogen $(\mathrm{g} / \mathrm{kg})$ & 7.23 & 3.78 \\
7 & Total Hydrocarbon Content $(\mathrm{mg} / \mathrm{kg})$ & 0.00 & 9.76 \\
8 & Total Heterotrophic Bacterial $(\mathrm{cfu} / \mathrm{g})$ & $8 * 10^{5}$ & $1.32 * 10^{5}$ \\
\hline
\end{tabular}

Results of Table 4 revealed that, the addition of used engine oil to the soil invariably alter the initial properties of the soil as follows;

i. The soil became acidic as the $\mathrm{pH}$ changes from the initial alkaline state of 9.4 to an acidic state of 3.60

ii. High level of conductivity occasioned by the presence of high concentration of dissolved solids as observed from the results of conductivity and total dissolved solids $(80 \mu \mathrm{S} / \mathrm{cm}$ and $52.8 \mathrm{mg} / \mathrm{l})$ was also observed.

iii. A drastic reduction in total nitrogen and total organic carbon concentration occasioned by a sudden increase in the hydrocarbon content of the soil due to contamination.

iv. It was also observed that the addition of used engine oil to the soil resulted in a drastic reduction in the total heterotrophic bacterial count from $8 \times 10^{5} \mathrm{cfu} / \mathrm{g}$ to $1.32^{\mathrm{x}} 10^{5} \mathrm{cfu} / \mathrm{g}$

The effect of substrate addition (bioremediation) on the total heterotrophic bacterial growth of used engine oil contaminated soil was studied for a period of 12 weeks. The graphical relationship between 
the total heterotrophic bacterial population and the remediation time for the different treatment substrate used is presented in Figure 1. The initial decrease in the bacterial count due to contamination from the used engine oil revealed the toxic effect of the used engine oil and possibly support the fact that some of the microorganisms present in the soil cannot survive in an environment contaminated with hydrocarbons emanating from used engine oil. This claim is in accordance with the reports by (Umanu and Nwachukwu, 2010).

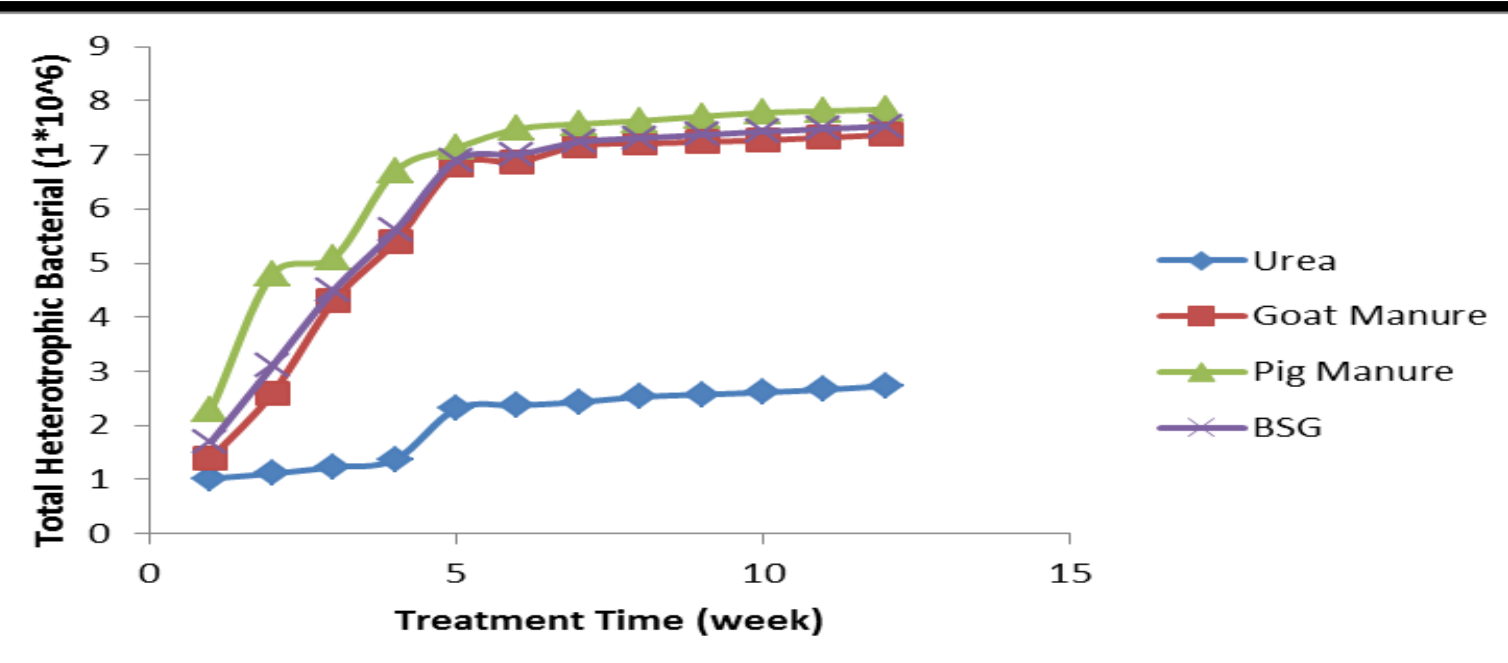

Figure 1: Variation of total heterotrophic bacterial with treatment time

Figure 1 revealed a continuous increase in the population of hydrocarbon utilizing microorganisms especially with the addition of treatment substrates, hence the higher reduction in residual used engine oil observed throughout the period of experimentation. Pig manure was observed to have the highest population of heterotrophic bacterial population followed by Brewery Spent Grain (BSG) and goat manure then urea in that order. The findings that pig manure possessed the highest population of total heterotrophic bacterial followed by BSG is in accordance with the results of Diez et al. (2001) which reported that pig manure is not only rich in mineral elements such as; nitrogen and phosphorous required for crude oil degradation, it also contain bacteria with varying degrees of crude oil degrading capabilities. The effect of substrate addition (Bioremediation) on the total nitrogen content was studied for a period of 12 weeks. The graphical relationship between the residual total nitrogen concentration and the remediation time with respects to all the substrate used is presented in Figure 2.

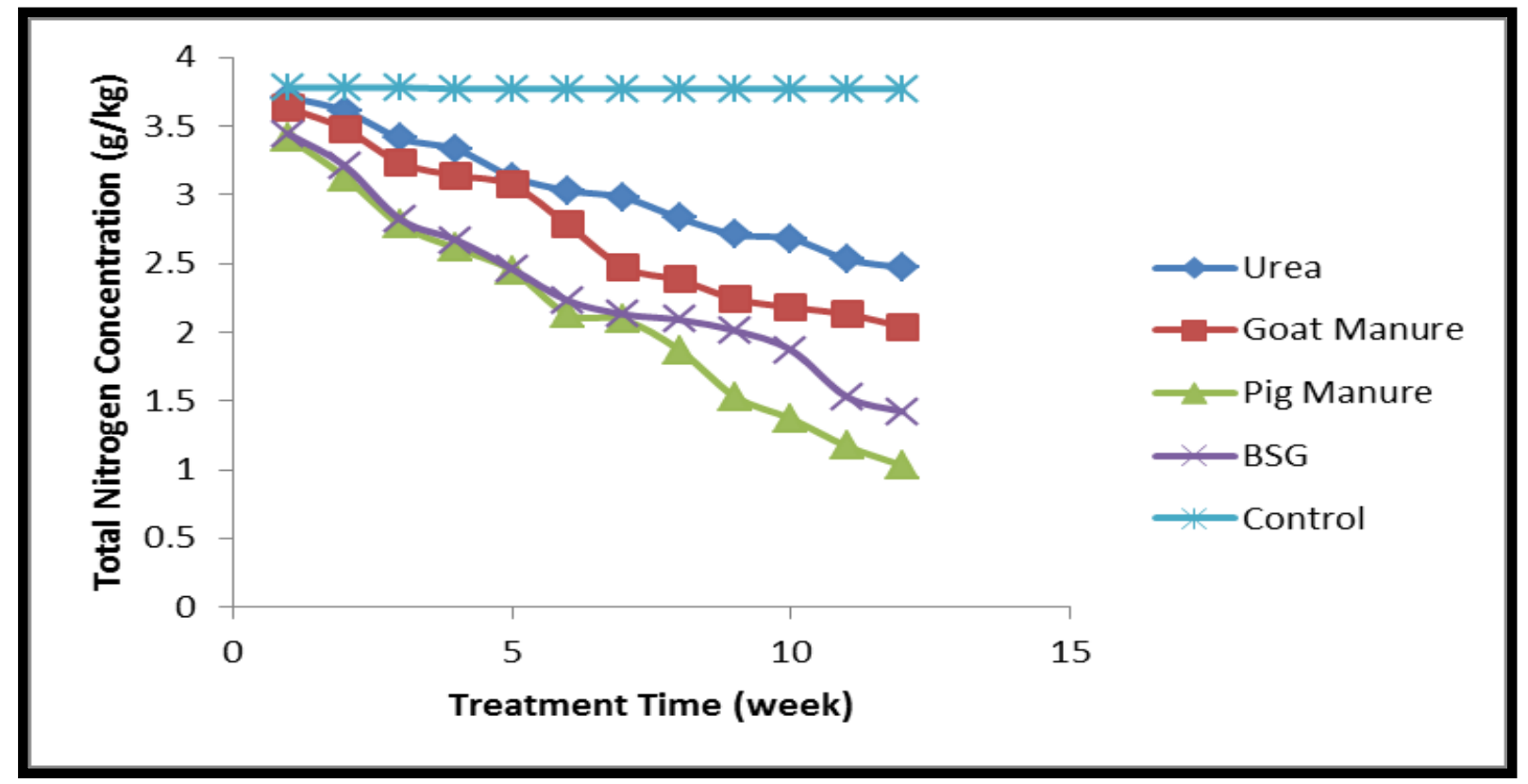

Figure 2: Variation of total nitrogen concentration with treatment time 
The gradual decrease in the total nitrogen content with increase in remediation time as observed in Figure 2 could be traced to the increase in the population of total heterotrophic bacterial count occasioned by nutrient utilization. Heterotrophic bacterial normally utilized the available nutrient in the form of total nitrogen, total organic carbon and total phosphorous for their growth and cell development; consequently, leading to a drastic reduction in the nutrient level. Therefore, as the remediation time increases, there is a corresponding increase in the population of total heterotrophic bacterial present in the treatment substrate due to utilization of available nutrient resulting to decline in the concentration of these nutrients. In addition, increase in bacterial population may lead to unhealthy competition for the available nutrients since the bacterial would need the nutrient for survival. It was also observed from the result of Figure 2 that pig manure possesses the highest population of heterotrophic bacterial as seen in the available concentration of nitrogen followed by BSG and goat manure in that order. This finding agrees completely with the results of Diez et al. (2001). The trend that applies to total nitrogen content due to substrate addition also applies to total organic carbon content since the nutrient level of soil is measured based on the concentration of total nitrogen, total organic carbon and total phosphorous content. The variation of total organic carbon with remediation time is presented in Figure 3.

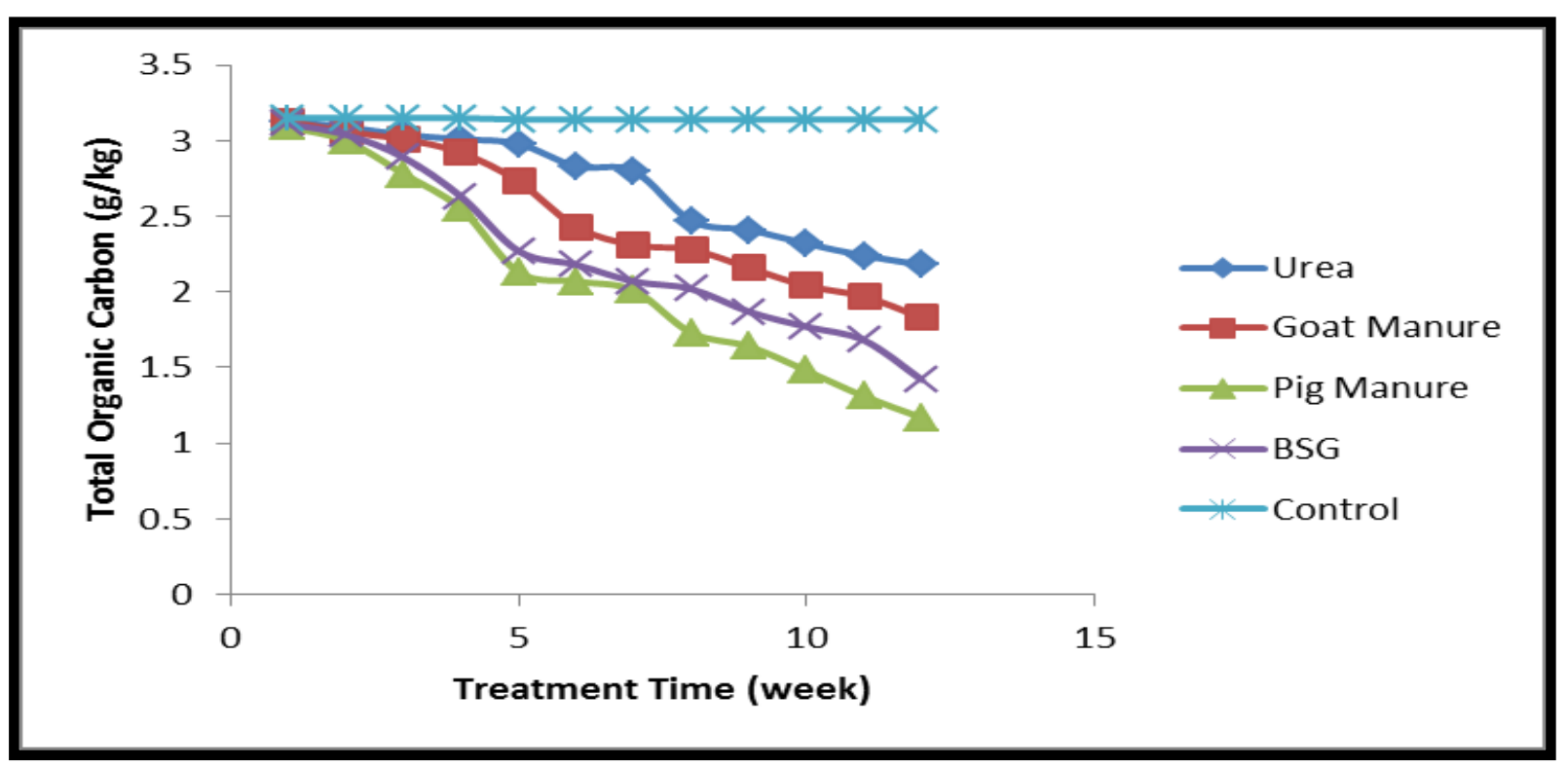

Figure 3: Variation of total organic carbon with treatment time

Like total nitrogen content, a gradual reduction in the total organic content (TOC) throughout the period of experimentation was also observed with remediation time. This reduction can also be attributed to the steady and continuous consumption of this nutrient by the microorganism for cell growth and development while also increasing in population. On the variation of total hydrocarbon content with remediation time, it was observed that the percentage reduction in total hydrocarbon content (THC) was relatively slow within the first two weeks of remediation in all the soil microcosms. The slow rate of hydrocarbon removal could be attributed to stability and adaptation of the microorganism to the hydrocarbon polluted environment. As the microorganism stabilizes and became well adapted to the environment, they tend to grow and developed based on the available nutrient while also eating up the hydrocarbon thus bringing about possible cleanup. This trend that defines the process of hydrocarbon remediation by microorganism based on substrate addition is presented in Figure 4. 


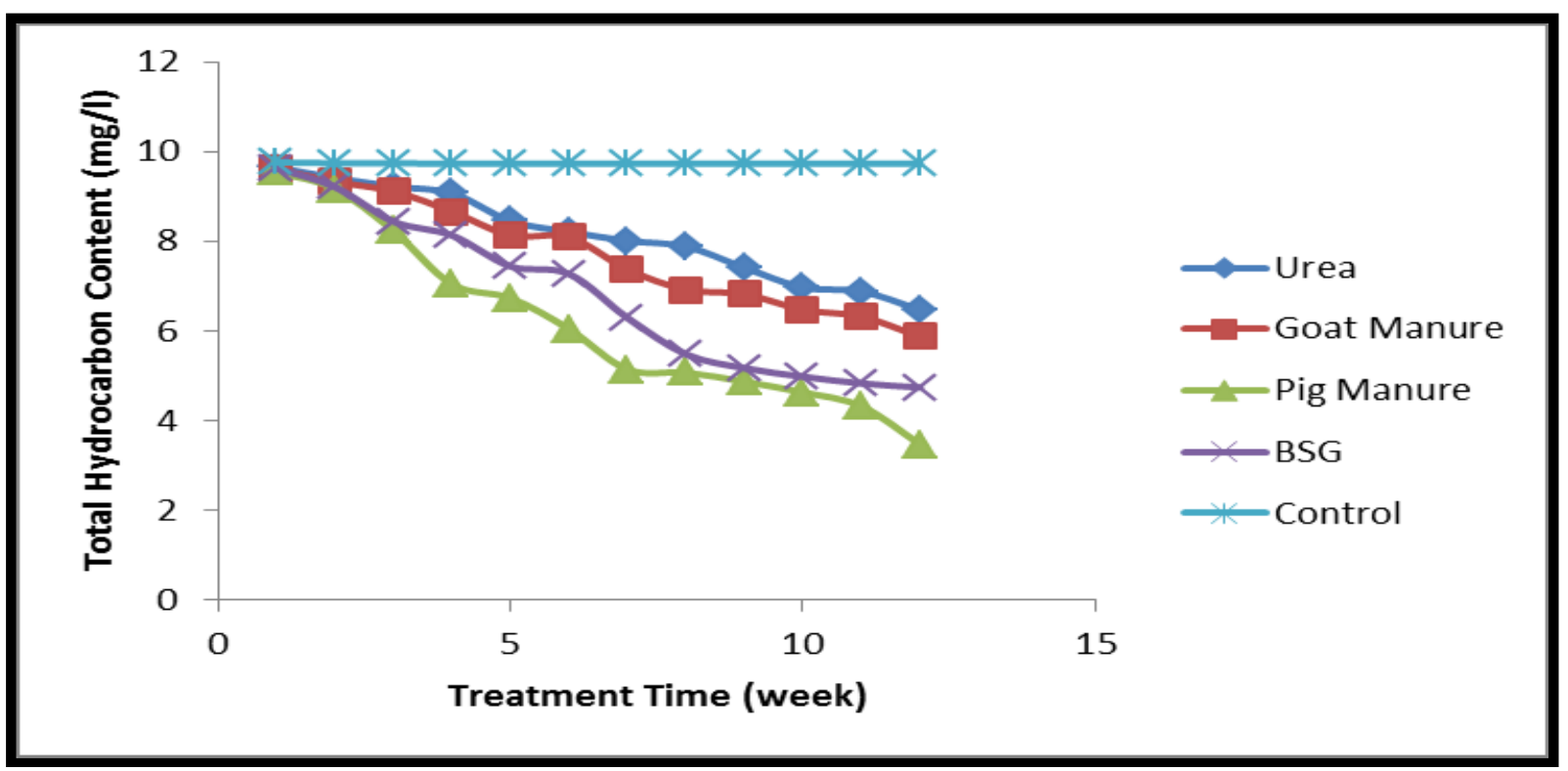

Figure 4: Variation of total hydrocarbon content with treatment time

Result of Figure 4 shows that pig manure is the best substrate for the cleanup of used engine oil polluted soil followed by BSG and goat manure in that order. At the end of the remediation time of 12 weeks it was observed that pig manure was able to reduce the concentration of the used engine oil hydrocarbon from the initial $9.76 \mathrm{mg} / 1$ to $3.47 \mathrm{mg} / \mathrm{l}$ while $\mathrm{BSG}$ reduces the concentration from $9.76 \mathrm{mg} / \mathrm{l}$ to $4.74 \mathrm{mg} / \mathrm{l}$. That of goat manure reduces from $9.76 \mathrm{mg} / \mathrm{l}$ to $5.87 \mathrm{mg} / \mathrm{l}$ while inorganic fertilizer (urea) reduces it from $9.76 \mathrm{mg} / \mathrm{l}$ to $6.47 \mathrm{mg} / \mathrm{l}$ respectively. The breakdown of petroleum hydrocarbon by the available microorganism resulted in the formation of carbonzylic acid as by product which in turn will have effect on the $\mathrm{pH}$ of the system. When the effects of substrate addition (Bioremediation) on the total $\mathrm{pH}$ of used engine oil contaminated soil was studied for a period of 12 weeks, results obtained is presented in Figure 5.

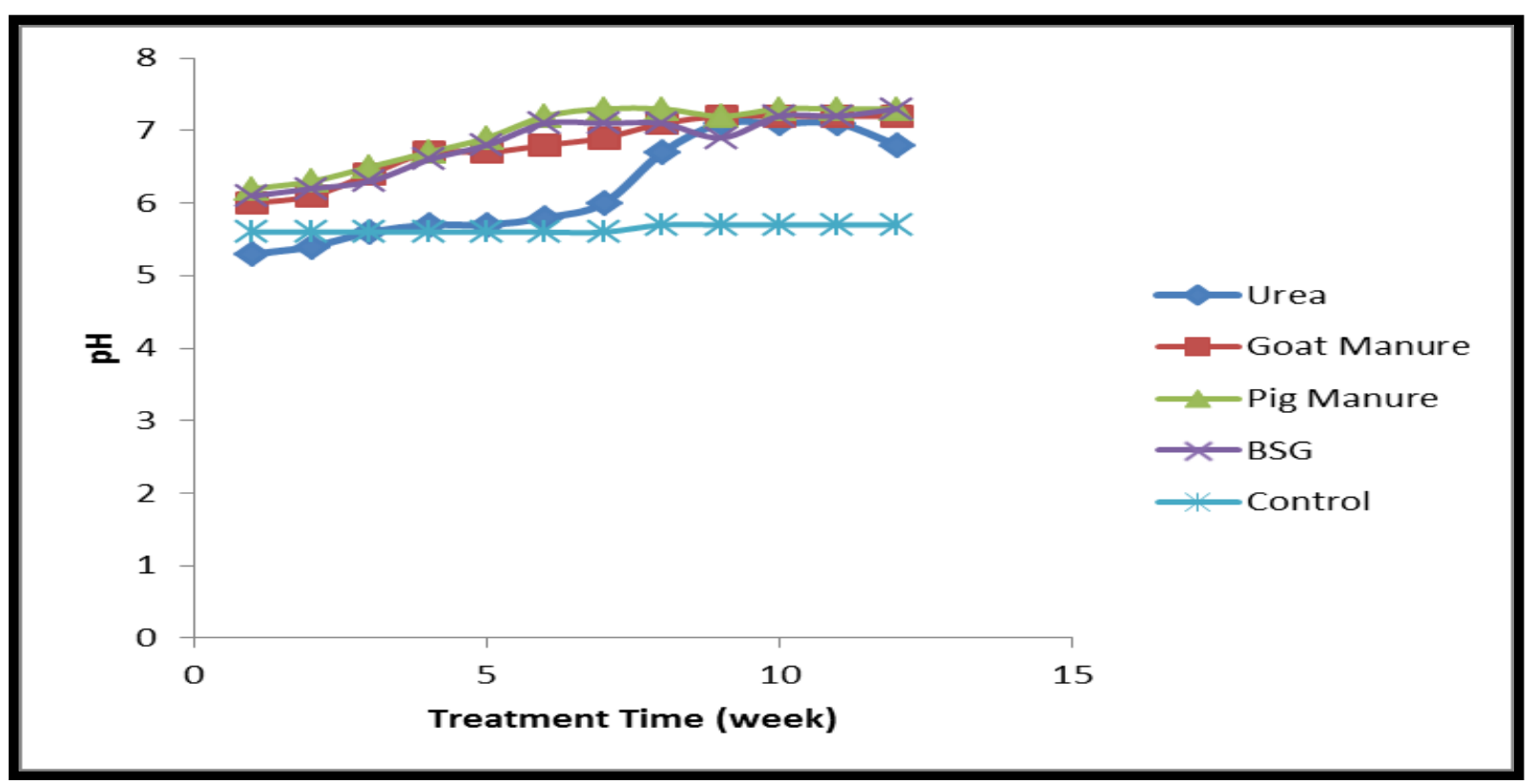

Figure 5: Variation of $\mathrm{pH}$ with Treatment Time

It was observed from the result of Figure 5 that pig manure raised the $\mathrm{pH}$ of the soil to a range between 6.2 and 7.3, which is ideal for crude oil utilizing bacteria as reported in (Vidali, 2001). This indicates that pig manure has a buffering effect on the soil which would have contributed to the enhanced hydrocarbon degradation since high level of acidity is a challenge in biodegradation. The use of pig manure to stimulate used engine oil biodegradation could be one of the severally sought environmentally friendly ways of eliminating petroleum hydrocarbon pollution problems in the 
natural ecosystem. More also BSG shows a substantial performance as another reliable material for the biodegradation of used engine oil contaminated soil. An initial reduction in $\mathrm{pH}$ value was observed for all the substrate used due to breakdown of hydrocarbon to acid fractions. The $\mathrm{pH}$ value of a soil sample is the most frequently determined parameter in soil analysis. It is the characteristic value of what is known as "soil reaction," and allows soils to be classified according to their acidity and alkalinity. The effect of substrate addition (bioremediation) on the electrical conductivity of used engine oil contaminated soil was also studied for a period of 12 weeks and result obtained is presented in Figure 6.

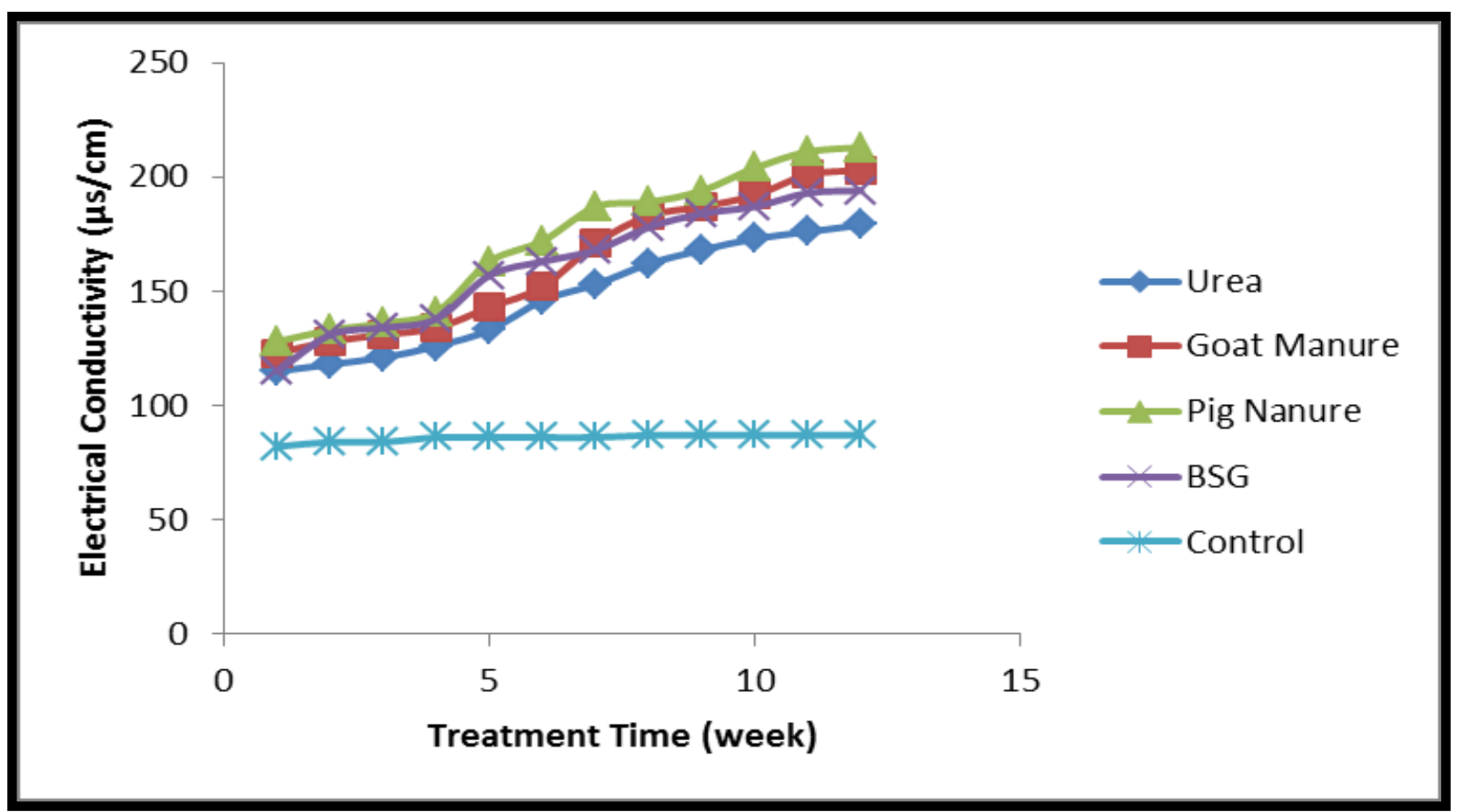

Figure 6: Variation of electrical conductivity with treatment time

The trend observed in Figure 6 was attributed to the presence of high level of dissolved ions occasioned by the breakdown of the hydrocarbon by the heterotrophic bacterial present in the substrate used. The linear trend of the control setup as observed in all the Figures indicate the complete absence of microorganisms due to lack of substrate addition. The graphical variation between the amount of used engine oil degradation and the efficiency of bioremediation with treatment time for all the substrate used is presented in Figures 7 and 8 respectively.

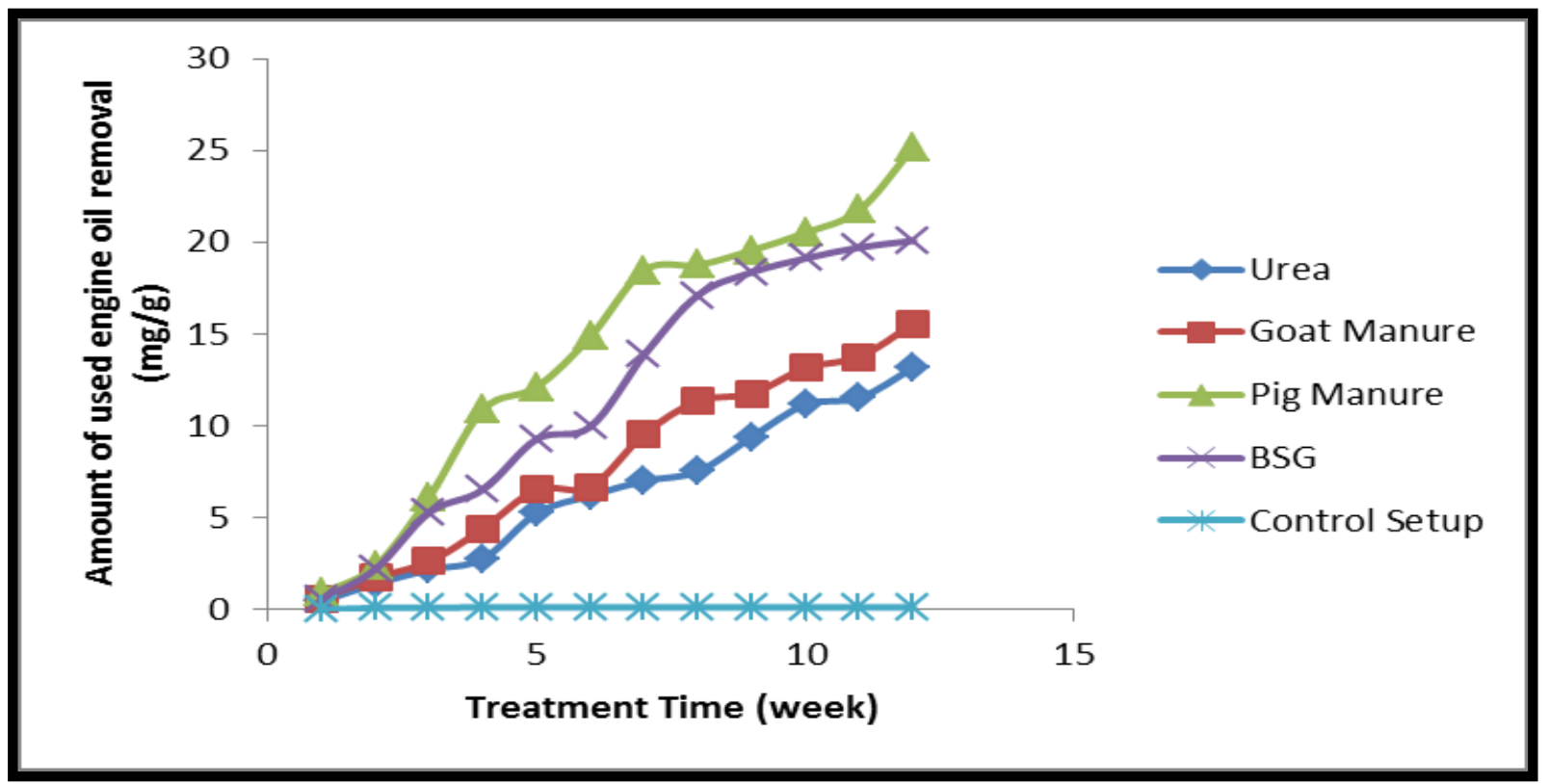

Figure 7: Amount of used engine oil removed with time 


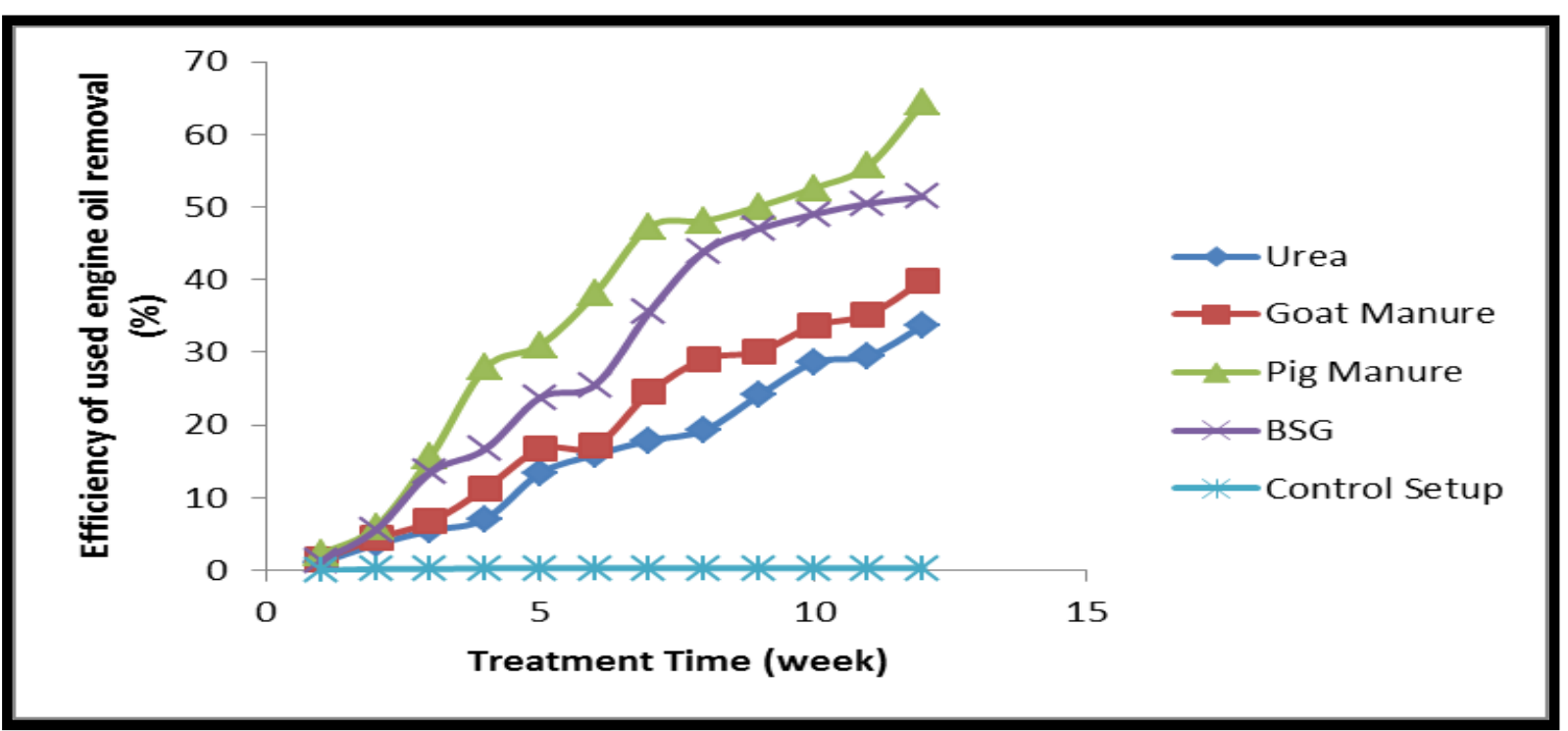

Figure 8: Efficiency of used engine oil removal with time

It can be deduced from the result of Figures 7 and 8 that, the efficiency of remediation increases with treatment time. Increase in the efficiency of remediation with treatment time can be traced to the increase in the population of the heterotrophic bacteria resulting from the gradual depletion of the available nutrients such as total organic carbon and total nitrogen. To determine the mathematical relationship between the efficiency of used engine oil degradation and remediation time, linear and non-linear regression modelling was done. To select the model that best explain this relationship, coefficient of determination $\left(\mathrm{r}^{2}\right)$ which measures the corresponding change in the dependent variable occasioned by change in independent variable was employed. Results of the linear and non-linear regression modelling are presented in Table 5. Based on the result of Table 5, the non-linear regression model was acclaimed the best model and can be employed to predict the maximum time required for complete remediation of used engine oil contaminated soil using any of the selected substrate.

Table 5: Parameters of linear and non-linear regression model

\begin{tabular}{|c|c|c|c|c|}
\hline $\mathrm{S} / \mathrm{N}$ & Model & Substrate & Model Equation & $\mathrm{R}^{2}$ \\
\hline \multirow{4}{*}{1} & \multirow{4}{*}{ Linear Regression } & Pig Manure & $Y=1.141+5.455 X$ & 0.950 \\
\hline & & BSG & $Y=-1.326+4.897 X$ & 0.956 \\
\hline & & Goat Manure & $Y=-2.495+3.592 X$ & 0.947 \\
\hline & & Urea Fertilizer & $Y=-2.861+3.000 X$ & 0.939 \\
\hline & & & & \\
\hline \multirow{4}{*}{2} & \multirow{4}{*}{$\begin{array}{l}\text { Non-Linear } \\
\text { Regression }\end{array}$} & Pig Manure & $F(x)=-0.3321 X^{2}+9.772 X-8.932$ & 0.9824 \\
\hline & & BSG & $F(x)=-0.2051 X^{2}+7.651 X-8.305$ & 0.9812 \\
\hline & & Goat Manure & $\mathrm{F}(\mathrm{x})=-0.0451 \mathrm{X}^{2}+4.178 \mathrm{X}-3.864$ & 0.9886 \\
\hline & & Urea Fertilizer & $\mathrm{F}(\mathrm{x})=0.02845 \mathrm{X}^{2}+2.631 \mathrm{X}-1.998$ & 0.9899 \\
\hline
\end{tabular}

Kinetic analyses allow estimation of bioremediation rates as well as determination of the appropriate rate equation characteristic of possible reaction mechanisms. Based on kinetic classification, bioremediation mechanism can be described by reaction-controlled or transport-controlled. Pseudofirst order and pseudo-second order kinetic models were applied in this study to describe the reactioncontrolled mechanism for the bioremediation of used engine oil contaminated soil using pig manure, brewery spent grain, goat manure and urea fertilizer. Film diffusion, and intra-particle diffusion models were applied to satisfactorily describe the transport or diffusion controlled mechanism. The graphical variation between the remediation time $(\mathrm{t})$ and $\log \left(\mathrm{q}_{\mathrm{e}}-\mathrm{q}_{\mathrm{t}}\right)$ based on pseudo-first order kinetic model is presented in Figure 9 while the variation between the remediation time $(t)$ and $\left(t / q_{t}\right)$ based on pseudo-second order kinetic model is presented in Figure 10. When the time dependent batch remediation data were analyzed using the film diffusion and intra-particle diffusion models, the results obtained are presented in Figures 11 and 12 respectively. 


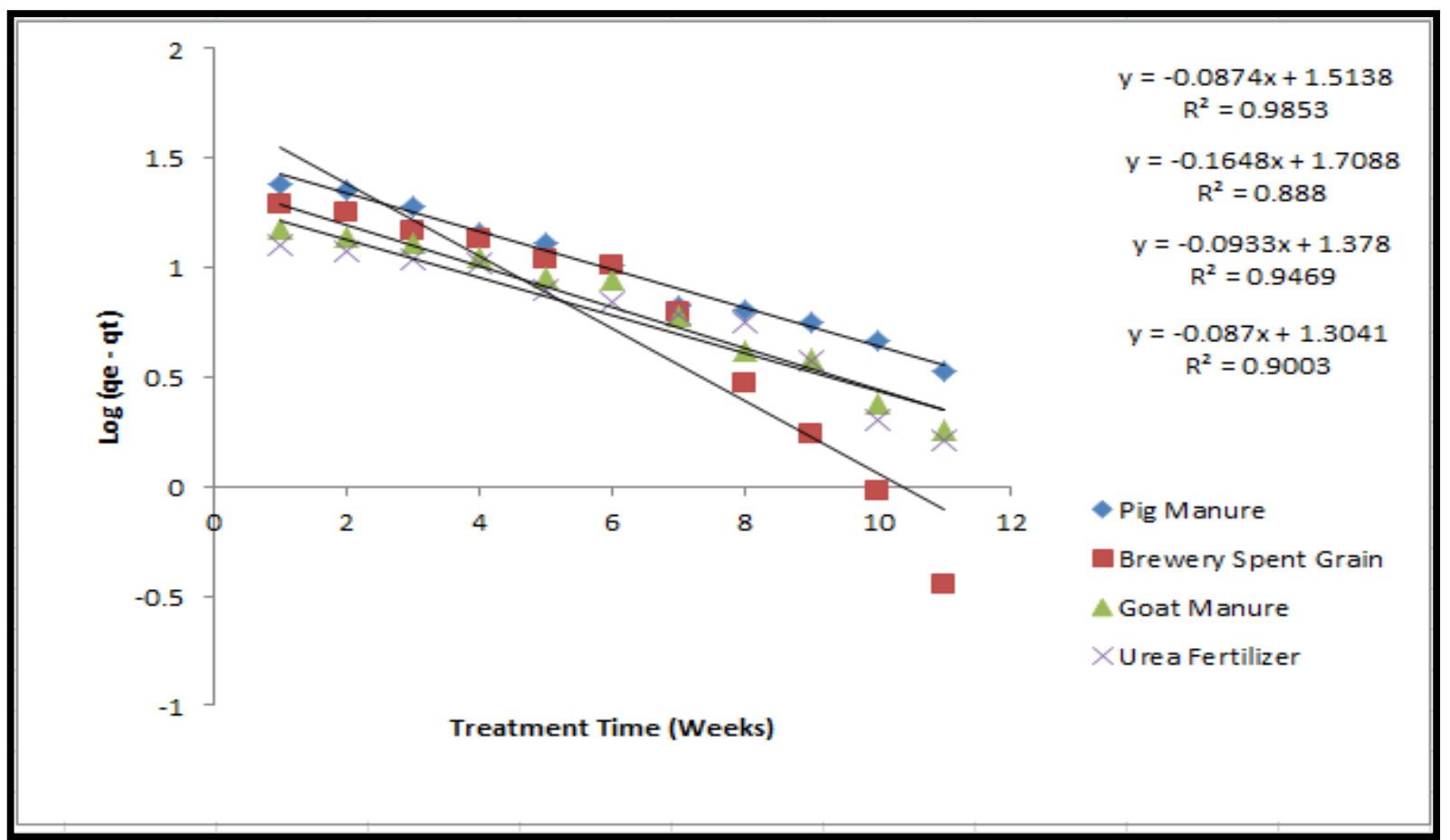

Figure 9: Pseudo-first order kinetic model for the bioremediation of used engine oil contaminated soil

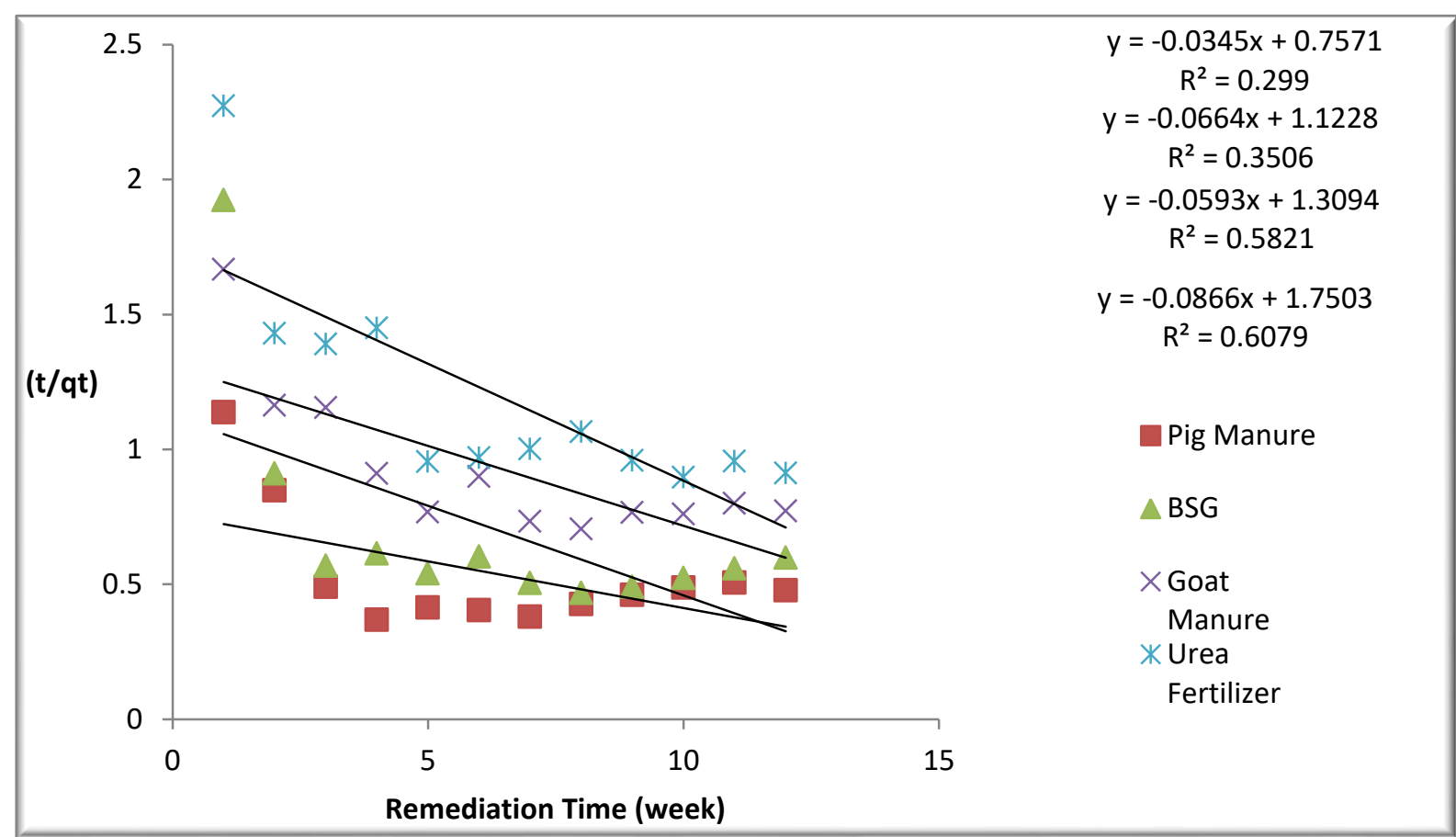

Figure 10: Pseudo-second order kinetic model for the bioremediation of used engine oil contaminated soil 


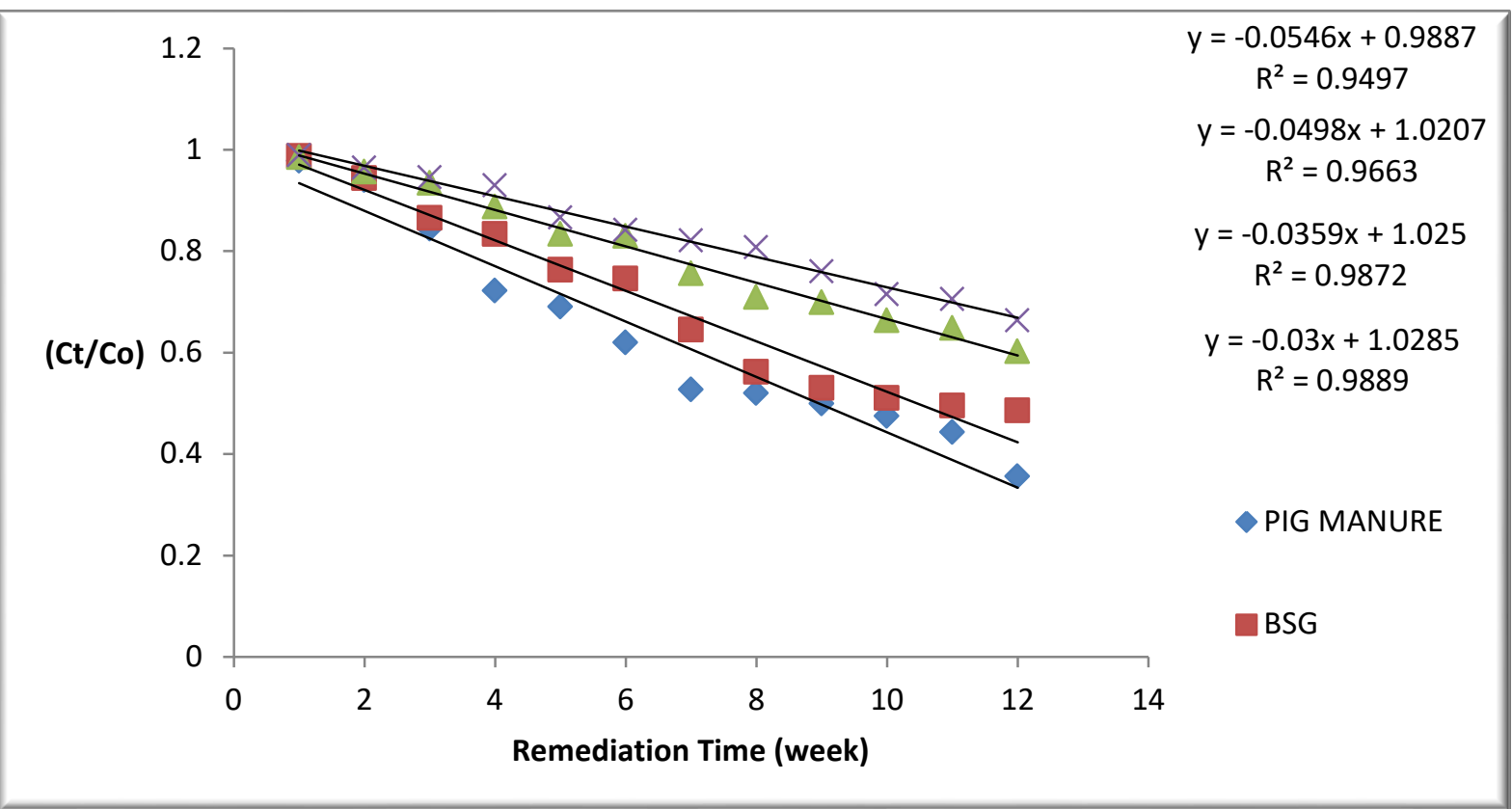

Figure 11: Film diffusion model for the bioremediation of used engine oil contaminated soil

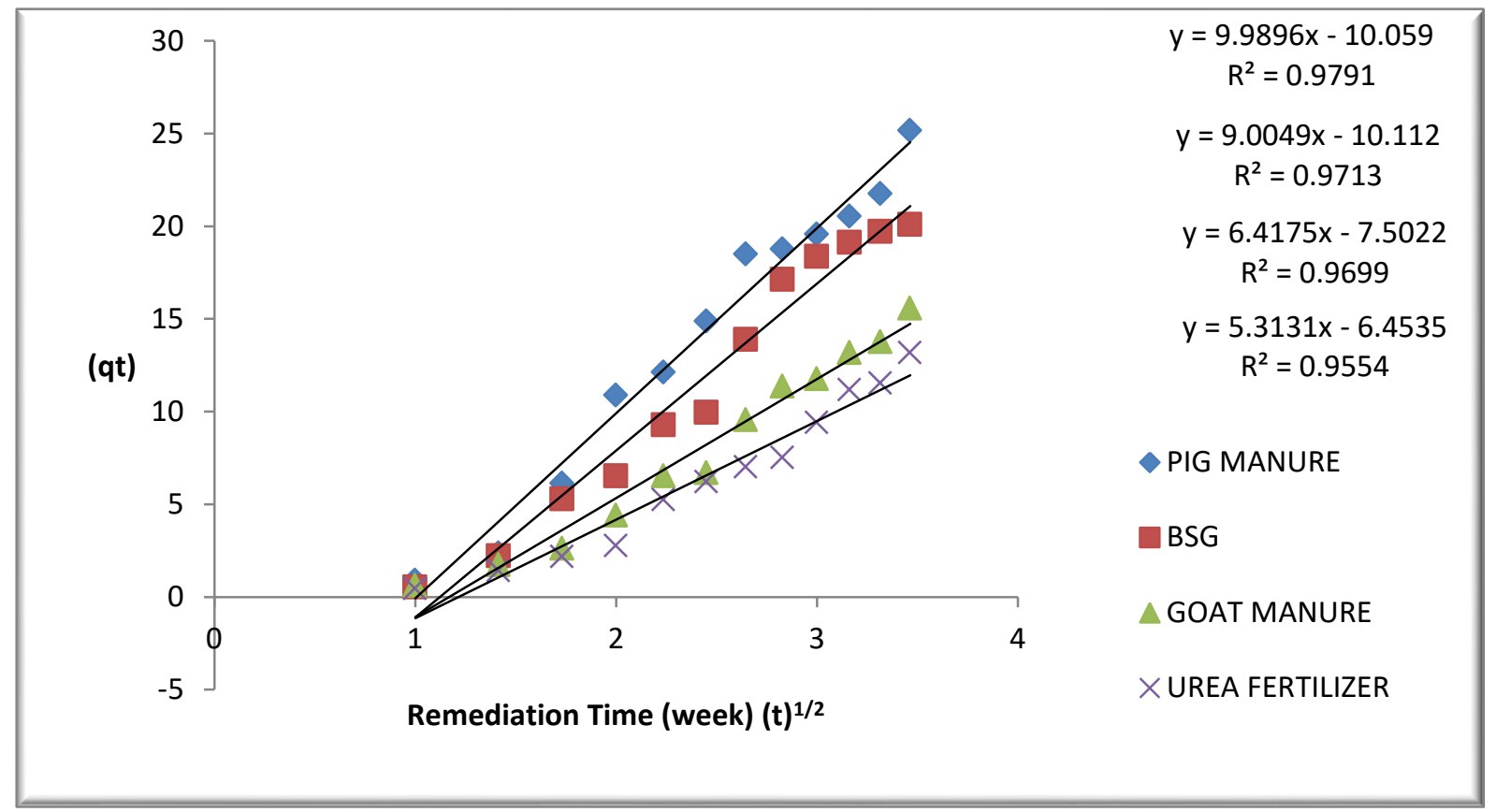

Figure 12: Intra-particle diffusion model for the bioremediation of used engine oil contaminated soil

Pseudo-first order kinetic model and pseudo-second order kinetic model were tested to study the reaction mechanism involved in the bioremediation of used engine oil contaminated soil using some selected substrate. Film diffusion was tested to study the diffusion of the particles of used engine oil after degradation through the boundary layer (film) while Intraparticle diffusion model was studied to understand the rate of internal diffusion occassioned by the transport of the particles of used engine oil after degradation within the pores of the substrate. If chemical reaction becomes the rate limiting step in the bioremediation process, then the bioremediation process will be a reaction controlled process. Conversely, if diffusion step is rate limiting, then the bioremediation process will be a diffusion controlled process. On the kinetics that best explains the experimental data, linear coefficient of determination was first employed as bases for judgment and result of Table 6 shows the computed values of $r^{2}$ for pig manure, brewery spent grain, goat manures and urea fertilizer based on the different kinetic models. 
Table 6: Computed coefficient of determination $\left(\mathrm{R}^{2}\right)$

\begin{tabular}{|l|l|l|l|l|}
\hline Kinetic Models & Pig Manure & BSG & Goat Manure & Urea Fertilizer \\
\hline Pseudo-first order & 0.9853 & 0.8880 & 0.9469 & 0.9003 \\
\hline Pseudo-second order & 0.2990 & 0.3506 & 0.5821 & 0.6079 \\
\hline Film diffusion & 0.9497 & 0.9663 & 0.9872 & 0.9889 \\
\hline Intra-particle diffusion & 0.9791 & 0.9713 & 0.9699 & 0.9554 \\
\hline
\end{tabular}

Based on the result of Table 6, the bioremediation of used engine oil contaminated soil using pig manure can best be described by using the pseudo-first order kinetic model. When brewery spent grain (BSG) was employed as the substrate, the remediation process can best be described by using intra-particle diffusion model. When goat manure was employed as the substrate, the remediation process can best be described by using film diffusion model. Finally, when urea fertilizer was employed as the substrate, the remediation process can best be described by using film diffusion model. Determination of $r^{2}$ value and its subsequent application in the selection of best fit kinetic model is not satisfactory owing to the alteration in the error structure associated with the transformation of non-linear kinetic equation to its linear form. In addition, $r^{2}$ value only account for the difference associated with each individual point fitted by the model in relation to the overall average of the fitted curve. Therefore, to have an accurate judgement in the selection of best fit kinetic model, non-linear error functions were employed. Error functions such as sum of error square (SSE), root mean square error (RMSE) and the residual average (RA) unlike $r^{2}$ accounts for the difference associated with each individual point fitted by the model in relation to each experimental point measured. Results of the computed kinetic parameters using the selected non-linear error functions are presented in Table 7.

Table 7: Computed error functions for selected kinetic models

\begin{tabular}{|c|c|c|c|c|}
\hline Model Parameters & Pig Manure & BSG & Goat Manure & Urea Fertilizer \\
\hline \multicolumn{5}{|l|}{ Pseudo-First Order } \\
\hline $\mathrm{q}_{\mathrm{e}}(\mathrm{mg} / \mathrm{g})$ & 102.92 & 148.54 & 270.28 & 280.94 \\
\hline $\mathrm{K}\left(\mathrm{min}^{-1}\right)$ & 0.0018 & 0.0011 & 0.0014 & $4.5 \mathrm{E}-03$ \\
\hline $\mathrm{R}^{2}$ & 0.9853 & 0.8880 & 0.9469 & 0.9003 \\
\hline SSE & 0.0002 & 0.0005 & 0.0012 & 0.0072 \\
\hline RMSE & 0.0028 & 0.0073 & 0.0082 & 0.0481 \\
\hline Average Residual & -0.412 & -0.556 & -0.798 & -0.884 \\
\hline \multicolumn{5}{|c|}{ Pseudo-Second Order } \\
\hline $\mathrm{q}_{\mathrm{e}}(\mathrm{mg} / \mathrm{g})$ & 45.713 & 12.233 & 7.1322 & 14.711 \\
\hline $\mathrm{K}_{2}(\mathrm{~g} / \mathrm{mg} / \mathrm{min})$ & 0.3355 & 0.3314 & 0.3376 & 0.3388 \\
\hline $\mathrm{R}^{2}$ & 0.2990 & 0.3506 & 0.5821 & 0.6079 \\
\hline SSE & 0.1432 & 0.2343 & 0.4467 & 0.8839 \\
\hline RMSE & 0.0457 & 0.0567 & 0.0844 & 0.1269 \\
\hline Average Residual & -2.221 & -4.416 & -5.029 & -7.106 \\
\hline \multicolumn{5}{|c|}{ Film Diffusion Model } \\
\hline $\mathrm{K}_{\mathrm{f}}(\mathrm{kg} / \mathrm{s})$ & 16.262 & 21.061 & 12.135 & 11.654 \\
\hline $\mathrm{W}(\mathrm{g})$ & 2.1066 & 1.3591 & 2.3443 & 3.7812 \\
\hline Sw (kg) & 0.2345 & 0.4561 & 0.9923 & 0.6534 \\
\hline $\mathrm{Vf}\left(\mathrm{m}^{3}\right)$ & 1.0345 & 2.1309 & 1.0034 & 1.3042 \\
\hline $\mathrm{R}^{2}$ & 0.9497 & 0.9663 & 0.9872 & 0.9889 \\
\hline SSE & 1.8394 & 1.3900 & 1.1471 & 2.0102 \\
\hline RMSE & 0.2562 & 1.0492 & 0.7972 & 0.3170 \\
\hline Average Residual & -1.044 & -1.645 & -1.4060 & -1.2650 \\
\hline \multicolumn{5}{|c|}{ Intra-Particle Diffusion } \\
\hline $\mathrm{K}_{\mathrm{ad}}(\mathrm{mg} / \mathrm{g} \min )$ & 23.262 & 45.061 & 26.133 & 31.602 \\
\hline I & 4.1013 & 3.3583 & 4.3256 & 6.1400 \\
\hline $\mathrm{R}^{2}$ & 0.9791 & 0.9713 & 0.9699 & 0.9554 \\
\hline SSE & 0.8367 & 0.3973 & 0.1498 & 0.8662 \\
\hline RMSE & 1.2567 & 2.4923 & 1.7909 & 2.0708 \\
\hline Average Residual & -1.078 & -1.886 & -1.065 & -1.642 \\
\hline
\end{tabular}

From the result of Table 7, it was observed that pseudo-first order kinetic model had the lowest calculated error sum of square and root mean square error with computed residuals almost close to zero. The calculated error sum of square (SSE) are $(0.0002,0.0005,0.0012$ and 0.0072$)$ while the computed root mean square errors (RMSE) are (0.0028, 0.0073, 0.0082 and 0.0481). Based on the calculated error values, it was concluded that the bioremediation of used engine oil contaminated soil 
using pig manure, brewery spent grain, goat manure and urea fertilizer is a reaction controlled process for which the reaction mechanism follows a pseudo-first order kinetic model.

\subsection{Conclusion}

Bioremediation is emerging as alternative technology for removing pollutants from the environment, restoring contaminated sites and preventing further pollution. Result of the study revealed that pig manure, Brewery Spent Grain (BSG), Urea Fertilizer and goat manure are effective for the biodegradation of used engine oil contaminated soil since they can facilitate the rate of breakdown of the hydrocarbon component of the used engine oil. In addition, pig manure was observed to have the highest population of heterotrophic bacterial followed by Brewery Spent Grain (BSG) and goat manure then urea fertilizer in that order. At the end of remediation time of 12 weeks' pig manure was acclaimed the best substrate for the clean-up of used engine oil contaminated soil with calculated removal efficiency of $64.4 \%$ followed by BSG with $51.4 \%$ removal efficiency, Goat Manure with removal efficiency of $39.9 \%$ and Urea Fertilizer with $33.7 \%$ efficiency.

Linear and non-linear regression analysis of the experimental data revealed that the non-linear regression analysis best explains the experimental data and can be employed to predict the maximum remediation time of used engine oil degradation. Results of the kinetic modelling based on the calculated error functions revealed that pseudo-first order kinetic model had a better fit to the experimental data. Finally, it was observed that for the entire period of experimentation (12 weeks), there was a gradual decrease in the total nitrogen content (TNC), total organic carbon (TOC) and total hydrocarbon content (THC) with remediation time. The use of pig manure, goat manure, brewery spent grain and urea fertilizer to enhance the degradation of used engine oil contaminated soil could be one of the severally sought bioremediation strategies of remediating natural ecosystem that is contaminated with petroleum hydrocarbons.

\section{References}

Abioye, P. O., Abdul Aziz, A. and Agamuthu, P. (2009). Enhanced biodegradation of used engine oil in soil amended with organic wastes. Water Air Soil Pollution, pp. 173-179.

Agarry, S. E., Mujidat, O. A., and Oluwafunmilayo, A. A. (2013). Kinetic Modeling and Half-Life Study on Enhanced Soil Bioremediation of Bonny Light Crude Oil Amended with Crop and AnimalDerived Organic Wastes. Journal of Petroleum and Environmental Biotechnology, 4(2).

Akinde, S. B. and Obire, O. (2008). Aerobic heterotrophic bacteria and petroleum-utilizing bacteria from cow dung and poultry manure. World Journal of Microbiology and Biotechnology, 24, pp. 1999-2002.

Ashtoukhy, E. S. Z., Amin, N. K. and Abdelwahab, O. (2008). Removal of lead (II) and copper (II) from aqueous solution using pomegranate peel as a new adsorbent. Desalination Journal, 223, pp. 162-173.

Burland, S. M. and Edwards, E. A. (1999). Anaerobic benzene biodegradation linked to nitrate reduction. Applied and Environmental Microbiology, 65(2), pp. 529-533.

Diez, J. A., Torre, A. I. and Cartagena, M. C. (2001). Waste management evaluation of the application of pig slurry to an experimental crop using agronomic and Eco toxicological approaches. J. Environ. Qual. 30, pp. 2165-2172.

Eba, F., Gueu, S., Eya, A., Mvongbote, A., Ondo, J.A., Yao, B.K., et al., (2010). Evaluation of the adsorption capacity of the natural clay from Bikougou (Gabon), to remove manganese (II) from aqueous solution. International Journal of Engineering science and technology, 2(10), pp. 5001-5016.

Grossi, V., Massias, D., Stora, G. and Bertrand, J. C. (2002). Exportation and degradation of acyclic petroleum hydrocarbons following simulated oil spill in bioturbated Mediterranean coastal sediments, Chemosphere, 48(9), pp. 947-954. 
Lagergren, S. and Svenska, B. K. (1998). Zur theorie der sogenannten adsorption geloester stoffe. Veternskapsakad Handlingar, 24 (4), pp. 1-39.

Mao, L. and Yue, Q. (2010). Remediation of diesel-contaminated soil by bioventing and composting technology. International Conference on Challenges in Environmental Science and Computer Engineering, pp. 3-6.

Molina-Barahona, L., Rodriguez-Vázquez, R., Hernández-Velasco, M., Vega-Jarquin, C., ZapataPérez, O., Mendoza-Cantú, A. and Albores, A. (2004). Diesel removal from contaminated soils by biostimulation and supplementation with crop residues. Appl. Soil Ecol., 27, pp. 165-175.

Okiemen, C. O. and Okiemen, F. E. (2005). Bioremediation of crude oil polluted soil: Effect of poultry droppings and natural rubber processing sludge application on biodegradation of petroleum hydrocarbon. Environ. Sci. 1(1), pp. 1-8.

Raghuvanshi, S. P., Singh, R, and Kaushik, C. P. (2004). Kinetics studies of Methylene blue dye bioadsorption on Bagasse. Applied Ecology and Environmental Research journal, 2(2), pp. 35 - 43.

Shamik, C. and Papita, S. (2010). Pseudo-second-order kinetic model for sorption of malachite green onto sea shells; comparison of linear and non-linear methods. The IIOAB Journals (Research Biophysics), 1(3), pp. 3-7.

Umanu, G. and Nwachuwkwu, S. U. (2010). The Use of Kitchen Effluent as Alternative Nutrient Source for Bioremediation of Oil Based Drilling Muds. Journal of Appl. Sci. Environ. Manage. 14(4), pp. 5-11.

Van-Lier, W. C. (1989). Mass Transfer to Activated Carbon in Aqueous Solutions, Ph. D. Thesis, Technical University of Delft, The Netherlands.

Vidali, M. (2001). Bioremediation: An overview. Journal of Pure Applied Chemistry, 73(7), pp. 1163-1172. 